\title{
Detailed biostratigraphy of the Santonian/Campanian boundary interval in Northern Israel
}

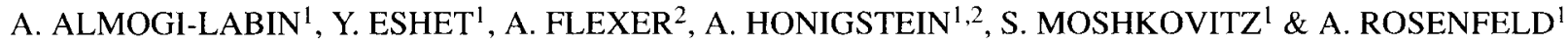 \\ 1. Geological Survey of Israel, 30 Malkhei Yisrael St., Jerusalem 95501, Israel \\ 2. Dept of Geophysics and Planetary Sciences, Tel Aviv University, Ramat Aviv 69978, Israel
}

\begin{abstract}
One of the best continuous and fossiliferous Late Santonian-Early Campanian successions in Israel is the approximately $6 \mathrm{~m}$ thick Kabri section in northern Israel. Its chalky marls were deposited in an outer shelf to upper slope environment with minor depth fluctuations. This Santonian/Campanian interval was studied examining calcareous nannoplankton, palynomorphs, ostracods and benthonic and planktonic foraminifera. The planktonic foraminiferal Dicarinella asymetrica - Glohotruncanita elevata concurrent range zone was first observed in Israel in the Kabri section. The first occurrence of Aspidolithus parcus parcus herein is characterized by small specimens, difficult to determine by light microscopy. The lower boundary of the Campanian in this sequence was defined by the first occurrence of G. elevata, in accordance with the ammonite stage definition. This datum line nearly coincides with the first occurrence of the nannofossil marker A. parcus parcus and with the base of the Leguminocythereis dorsocostata (S-4) ostracod zone, both slightly above the foraminiferal boundary.
\end{abstract}

\section{INTRODUCTION}

Coniacian-Maastrichtian sediments in northern Israel consist generally of rather homogenous chalky units (Mount Scopus Group; Flexer, 1968). The Late Coniacian-Campanian white chalks, up to $200 \mathrm{~m}$ thick, are grouped into the En Zetim Formation. The Kabri Marl (Baida, 1964) is an intercalation within this formation, representing a clear marker in the uniform succession. It was re-sampled for this study in its type section at the quarry, 2km SSE of Kibbutz Kabri (coordinate 16518/26738, Israeli grid; Fig. 1). This is the only known fresh exposure of this unit, which is generally covered by thin layers of soil or caliche. One sample (AF 751; Fig.2) was taken from the underlying massive chalk of the En Zetim Formation near to the lithologic boundary, whereas nineteen samples were taken from the approximately six metres thick section of the Kabri Marl (AF 752770). This unit consists of soft chalky marls with minor shaly layers of yellowish-greyish colour. The upper boundary of the Kabri Marl with the overlying white chalks (AF 771-774) exhibits an irregular wavy contact with a dark greyish clay layer of about $2 \mathrm{~cm}$ thickness at the contact (part of sample AF 771). The Kabri Marl section is very fossilifenous, with Gryphaea vesicularis and Scala goryi in its middle part, as well as Baculites sp. at its top. The section was dated by foraminifera as Early Campanian (Baida, 1964). The aim of the present study is to re-examine the Santonian-Campanian interval of this section by means of multiple micropalaeontological methods.

\section{MICROPALAEONTOLOGY}

Twenty-four samples from the Kabri section were examined for their foraminifera, ostracod and calcareous nannoplankton content
(Figs 2-5). All contained assemblages of the three fossil groups. In addition, fish teeth, prisms of Inoceramus, coprolites and phosphatic grains were found in some washed residues. Three of the samples (AF 752, 771 and 774) were also palynologically analysed. Some significant fossils of each group are figured on Plates 1 and 2.

\section{CALCAREOUS NANNOFOSSILS}

Nearly all samples were found to be rather rich in calcareous nannofossils and some samples form nanno-ooze. The assemblages are usually widely diversified and contain more than fifty species (Fig.2). Most of the species were already recorded in Late Cretaceous sediments of this part of Tethys (Moshkovitz, 1967, 1984, 1987; Shafik \& Stradner, 1971; Naji, 1983; Gvirtzman et al. 1985, 1989; Reiss et al. 1985). The fossils in the Kabri section are rather well preserved, but in some samples recrystallization or etching is observed. The section can be divided into three nannofossil biozones (see Sissingh, 1977; Perch-Nielsen, 1979, 1985):

Samples AF 751-754: Lucianorhabdus cayeuxii (CC 16) Zone Late Santonian

Samples AF 755-756: Calculites obscurus (CC 17) Zone - Late Santonian-earliest Campanian

Samples AF 757-772: Aspidolithus parcus (CC 18) Zone - Early (not earliest) Campanian

The biozonation of the highest samples, AF 773-774, is not clear. 


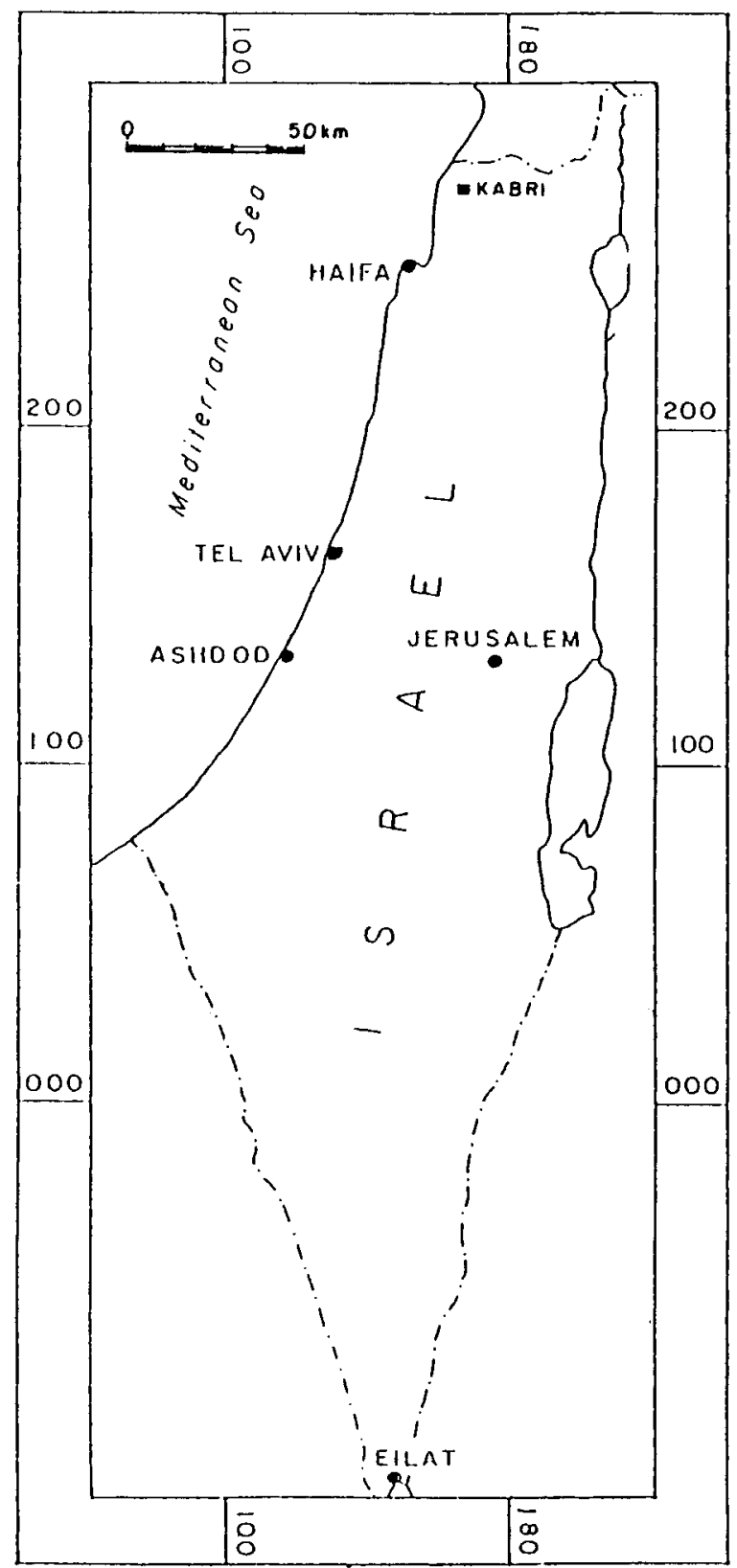

Fig.1. Location Map.

The Lucianorhabdus cayeuxii (CC 16) Zone is the lowermost nannofossil zone in our section. Here, nannofossils are common and moderately or poorly preserved, showing some etching and recrystallization. The CC 16 Zone was defined by Sissingh (1977) as the interval from the first occurrence (FO) of $L$. cayeuxii to the regular FO of Calculites obscurus. Only the uppermost part of this zone, (Late Santonian) is represented in the Kabri section. The assemblage is dominated by Watznaueria barnesae (Pl.1 fig.8), accompanied among others by Eiffellithus eximius, Aspidolithus furtivus (P1.1, fig.2), Broinsonia dentata (P1.1, fig.1), Micula decussata, Thoracosphaera spp., Helicolithus cuneatus, Gartnerago obliquum, Reinhardtites anthophorus, Lucianorhabdus cayeuxii, Lithraphidites carniolensis, Prediscosphaera cretacea and Marthasterites furcatus.

This assemblage is overlain by the Calculites obscurus (CC 17) Zone. The samples contain abundant coccoliths. The preservation of the fossils is, in general, poor to moderate, some etching or slight recrystallization is noted. The $\mathrm{CC} 17$ Zone is defined as the interval between the regular FO of $C$. obscurus to the FO of Aspidolithus parcus and as Late Santonian-earliest Campanian in age (Sissingh, 1977; Perch-Nielsen, 1985). The occurrence of C. obscurus in the Late Santonian (Sissingh, 1977, p.52; Doeven, 1983, pp.13, 24; but Campanian according to Perch-Nielsen, 1985, p.362) is confirmed also in the Kabri section. There, C. obscurus (Pl.1, fig.15) occurs rarely, although it is present in most layers above sample AF 754. The dominating species in this zone are $W$. barnesae, E. eximius, $P$. cretacea and Thoracosphaera spp. These are accompanied by rare to few occurrences of A. furtivus, $H$. cuneatus, $M$. furcatus, Eprolithus floralis and Calculites ovalis. All these species are known in Santonian sediments from various parts of the world.

The Aspidolithus parcus (CC 18) Zone is the uppermost zone in our section. The samples contain abundant nannofossils and sometimes form nanno-ooze. The preservation of the fossils is usually good, although some etching and recrystallization is observed, especially in the lower part of this zone. The CC 18 Zone is defined as the interval between the FO of $A$. parcus and the LO of $M$. furcatus and as Early (not earliest) Campanian in age (Sissingh, 1977; Perch-Nielsen, 1979, 1985). Due to the lack of upper successive samples, its upper boundary in the Kabri section is not clear enough to accurately mark the LO of $M$. furcatus. The assemblage in our samples is dominated by $W$. barnesae, Zygodiscus spp., Thoracosphaera spp., E. eximius and $L$. carniolensis. These fossils are accompanied among others by Arkhangelskiella specillata (PI.1, figs 7, 14), A. cymbiformis, A. furtivus, $B$, dentata, $R$. anthophorus, A. parcus expansus (Pl.1, fig.3), $H$. cuneatus, $M$. furcatus, Lithastrinus grilli (Pl.1, figs 9 , 17) and $C$. obscurus. The most indicative Campanian nannofossil species Aspidolithus parcus parcus was found from sample AF 757 upwards. The specimens of this form in the lowest samples of the CC 18 Zone (AF 757-758) are about 5-6 microns in size (Pl.1, figs 4-5) and difficult to determine by light microscopy. They attain an average size of 10-12 microns in the upper samples (e.g. AF 772; Pl.1, figs 6, 13), thus confirming the evolutionary trend, as suggested by Lauer (1975). This species must be included in the genus Aspidolithus Noel and not in Broinsonia Bukry. The latter genus, designated by the type-species B. dentata (Bukry, 1969, Pl.2, figs 1-3; Hattner \& Wise, 1980, Pl.5, figs 6-8), has a tapering central cross and lacks the round pores in the central arca (see Pl.1, fig.1), and is not appropriate for species such as parcus. In the uppermost sample AF 774, forms already close to $A$. parcus constrictus could be observed. Their subspecific designation, however, remains questionable, since their central area is somewhat wider (b/a ratio around 1.0, see Hattner et al., 1980; Wise, 1983). Samples higher up might provide more information on the evolutionary lineage of the Aspidolithus-Broinsonia group along the Santonian-Campanian boundary interval (see suggestions and discussions in Lauer, 1975; Perch-Nielsen, 1979: 


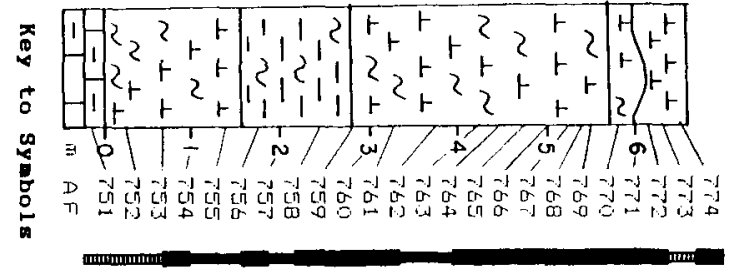

$0 \times 00 \times 0$ mano00amamamax

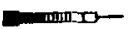

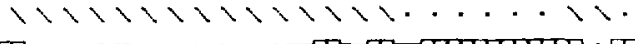

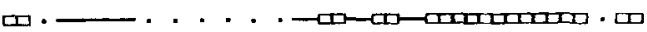
"

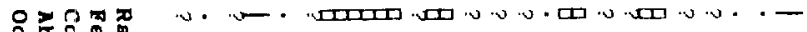

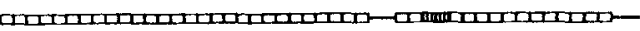

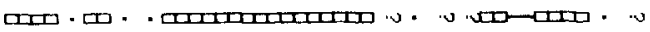
ס CIII. . . . . . . . . . . . - . . .

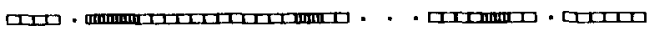

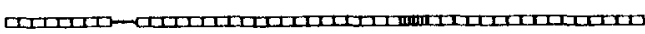
Cᄃ드.

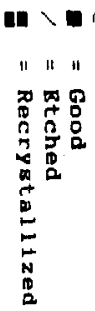

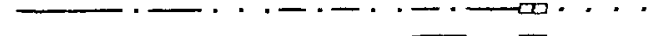

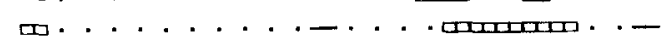

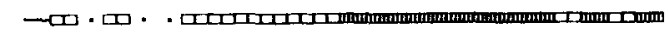

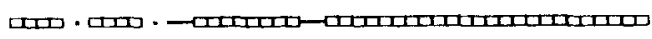

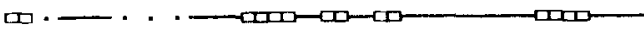

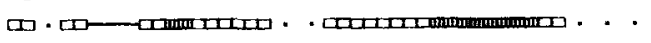
_......... . . . . . . D. . -

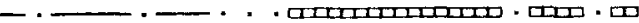

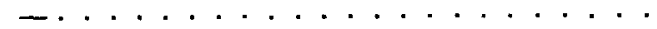

10

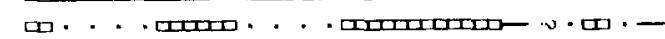
"

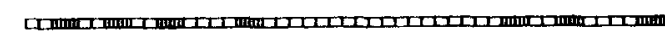

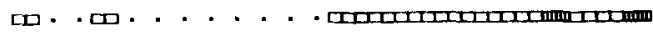
ט. mexummina

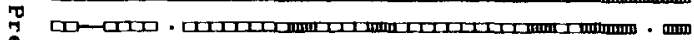

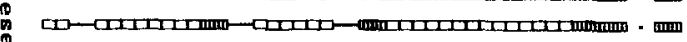

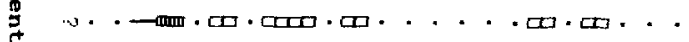
..................... . 口а... . . . . . . . . . . . .

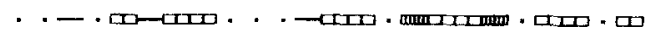

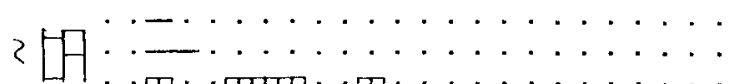

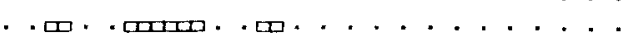

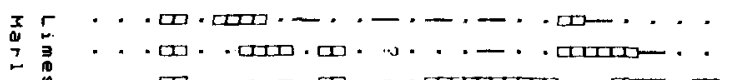

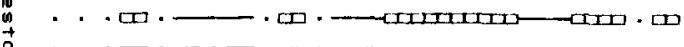
o . . . - . - . . . . . . . . . . .

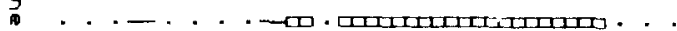
... . . . . . . . . . . . . . . . . . . . . . . . . . . . .. . . . . . . . . . . . . . . . . . .

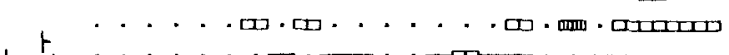
$l_{1} t_{f} \ldots \ldots \ldots-\cdots$

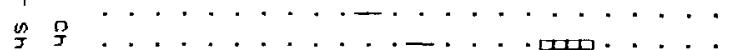

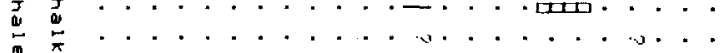

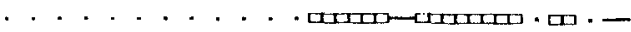

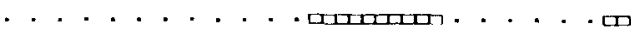
.. . . . . . . . . . . . . . .......................

\section{ii AgUNDANCE \\ PRESERUATION IGENERAL}

PRESERUATION IMOOE:

Ahmuerel la octoradiata

Arkhangelskiella cymbiformis

Arkhangelskiella specillata

Arkhangelskiella spp.

Brainsonia dentata

chiastozugus sp.

"Carrolitithion signum

Cretarhabdus crenulatus

II Cribrosphaerella ehrenbergi

Eiffelitithus eximius

III Eiffellithus turriseiffeli

Gartneraga obliquum

"Haqius circumradiatus

II HeIicolithus curieatus

II Kamptnerius magnifacus

Lithraphidites carniolensis

"Lucianarhabdus cayeuxi

"Ianiuitelia pemmatoidea

"Marthasterites furcatus

"Microrhabolulus decaratus

"Iicula decussata

II Parhabdalithus embergeri

II Frediscosphaera cretacea

"i" Quadrum sp.

Reinhardtites anthophorus

II Rhagodiscus angustus

II stowerius biarcus

II Tharacosphaera sp.1. ino pores

II Thoracosphaera sp. 2 ifew pores

"I Tranolithus oridnatus

"Watznaueria barnesae

il zugodiscus compactus

"II Zugodiscus diplogrammus

II 24901 ithus erux

Rucinolithus hayi

Uagalapilla matalosa

Culinaralithus serratus

Heteromarginatus sp.

Pontosphaera multicarinata

Eugodiscus sp. ilarge:

Aspidolithus furtius

Aspidalithus parcus expanaus

Calculites qualia

II Eprolithus floralis

Watznaversa biporta

"II

Calculites obscurus

"Ispidolithus parcus parcus

II Chiastozugus 1 itterarius

"I Lithastrinus grilli

"I Scampanella cornuta

II Cretarhabdus conicus

"linhardtites leuis

Rhagadiscus asper

II" Tranolithus gabalus

II Bsutum blacki i

"Hexalithus gardetae

Fig.2. Distribution chart of calcareous nannofossils in the Kabri Marl section. 
Hattner et al., 1980; Crux, 1982; Wise, 1983; Stradner \& Steinmetz, 1984). Marthasterites furcatus (PI.1, figs 11-12) is also an important species, its LO is known to occur in the early Campanian, somewhat above the $\mathrm{FO}$ of $A$. parcus parcus. In our section, $M$. furcatus is found up to sample AF 772. Hexalithus gardetae, another indicative form for the Campanian stage (PerchNielsen, 1985, p.390) is found in sample AF 771. Large specimens of Helicolithus (=Chiastozygus) cuneatus (Lyu'leva) Cepek \& Hay (Pl.1, fig.16) are rare in the Kabri section, but occur together with $A$, parcus parcus. The species differs from Eiffellithus trabeculatus (Gorka, 1957) of Albian-Maastrichtian age (Thierstein, 1976, p.339) by its larger form and the symmetrical cross. These forms usually accompany the Santonian nannofossil assemblages in central and southern Israel (Gvirtzman et al. 1985, 1989), where they occur below the FO of $A$. parcus parcus. A similar occurrence of large $H$. cuneatus was recorded in Early Campanian sediments from Site 511 in the South Atlantic DSDP Leg 71 under the species name Eiffellithus trabeculatus (Wise, 1983, p.491).

\section{PALYNOLOGY}

Only a few, non indicative dinoflagellate cysts were found in samples AF 752 and 774. Sample AF 771 contains Manumiella spp. and some other poorly preserved dinoflagellates. Terrestrial plant particles, such as cuticles tracheids and inertinites, are relatively common in this sample. The occurrence of many fungal cells (Pl.1, figs 19-21), originating on land, is noteworthy.

\section{OSTRACODS}

Ostracods are generally common to rare in the samples, only sample AF 754 yields abundant ostracods. The assemblages are relatively highly diversified and twenty-seven species, belonging to eighteen genera, were observed (Fig.3; for taxonomy see Honigstein, 1984). The section can be subdivided into three parts: the S-3 ostracod Zone (AF 751), the S-3b Subzone (AF 753-757) and the S-4 Zone (AF 758-774).

The exclusively Santonian species Cythereis cretaria occurs only in the lowermost sample and indicates, together with Limburgina miarensis and Cythereis cretaria dorsocaudata, the $L$. miarensis (S-3) assemblage zone of Late Santonian age (Honigstein, 1984; Honigstein et al., 1987). Occurring above this level and upwards are, among other species, Cytherella aff. eliotti, Krithe solomoni (Pl.2, fig.14) and Bythocypris aff. howchiniana, which appear in the subzone S-3b of the hitherto undefined Santonian-Campanian boundary interval (see references above).

The samples AF 758-774 belong to the overlying Leguminocythereis dorsocostata ( $\mathrm{S}-4)$ assemblage zone. The lower boundary of this zone in the Kabri section is defined by the FO of $P$. campania. Juvenile forms of this species were found from sample AF 758 upwards, already showing the development of subanterior ribs, typical for P. campania (Honigstein, 1984, p.17). Adult forms of $P$. campania (Pl.2, fig.12) occur together with $L$. dorsocostata (Pl.2, fig.11) from sample AF 765 and upwards. Eucytherura tetracornis (Pl.2, fig. 13) ranges in this section from AF 758 and upwards within the S-4 Zone.

\section{FORAMINIFERA}

The foraminiferal assemblage composition in the Kabri marl section was first investigated by Baida (1964). Most of the species determined are benthonic foraminifera and several of them were left in open nomenclature. Only five planktonic foraminiferal species were recognized in the section. The Early Campanian age determination (Baida, 1964) was based only on general ranges of the fauna and should be re-evaluated.

The present study shows that benthonic and planktonic foraminifera dominate the $>63$ microns size fraction in our samples (Figs 4, 5). The species are usually well preserved. The planktonic foraminifera are more abundant than the benthonic

Explanation of Plate 1

Calcareous nannoplankton and palynomorphs from the Kabri section (scale bar for figs 1-18, 1 $\mu \mathrm{m}$ for figs 19-21, 10 $\mu \mathrm{m}$.).

Fig.1. Broinsonia dentata Bukry, dorsal view, SEM micrograph, sample AF-766 (CC 18 Zone).

Fig.2. Aspidolithus furtivus (Bukry) Perch-Nielsen, dorsal view, SEM, sample AF-766 (CC 18 Zone).

Fig.3. Aspidolithus parcus expansus (Wise \& Wattkins) Perch-Nielsen, dorsal view, SEM, sample AF-758 (CC 18 Zone).

Fig.4. Aspidolithus parcus parcus (Stradner) Noel, dorsal view. SEM, sample AF-757 (CC 18 Zone).

Fig.5. Aspidolithus parcus parcus (Stradner) Noel, dorsal view, SEM, sample AF-758 (CC 18 Zone).

Fig.6. Aspidolithus parcus parcus (Stradner) Noel, dorsal view, SEM, sample AF-772 (CC 18 Zone).

Fig.7. Arkhangelskiella specillata Vekshina, dorsal view, SEM, sample AF-766 (CC 18 Zone).

Fig.8. Watznaueria barnesae (Black) Perch-Nielsen, coccosphere, SEM, sample AF-771, CC 18 Zone).

Fig.9. Lithastrinus grilli Stradner, top view, SEM, sample AF-766, (CC 18 Zone).

Fig. 10. Stoverius biarcus (Bukry) Perch-Nielsen, side view, SEM, sample AF-766 (CC 18 Zone).

Fig.11. Marthasterites furcatus Deflandre, SEM, sample AF-758, (CC 18 Zone).

Fig.12. Marthasterites furcatus Deflandre, LM. Pol. photograph, sample AF-770 (CC 18 Zone).

Fig.13. Aspidolithus parcus parcus (Stradner) Noel, distal view, LM. Pol., sample AF-771, (CC 18 Zone).

Fig.14. Arkhangelskiella specillata Vekshina, proximal view, LM. Pol., sample AF-761 (CC 18 Zone).

Fig.15 Calculites obscurus (Deflandre), Prins \& Sissingh, LM. Pol., sample AF-756 (CC 17 Zone).

Fig.16. Helicolithus (=Chiastozygus) cuneatus (Lyu’leva) Cepek \& Hay, LM. Pol,, sample AF-770 (CC 18 Zone).

Fig. 17. Lithastrinus grilli Stradner, LM. Pol., sample AF-760 (CC 18 Zone.

Fig. 18. Scampanella cornuta Forchheimer \& Stradner, LM. Pol, sample AF-761 (CC 18 Zone).

Figs 19-21. Fungal cells, sample AF-771. 


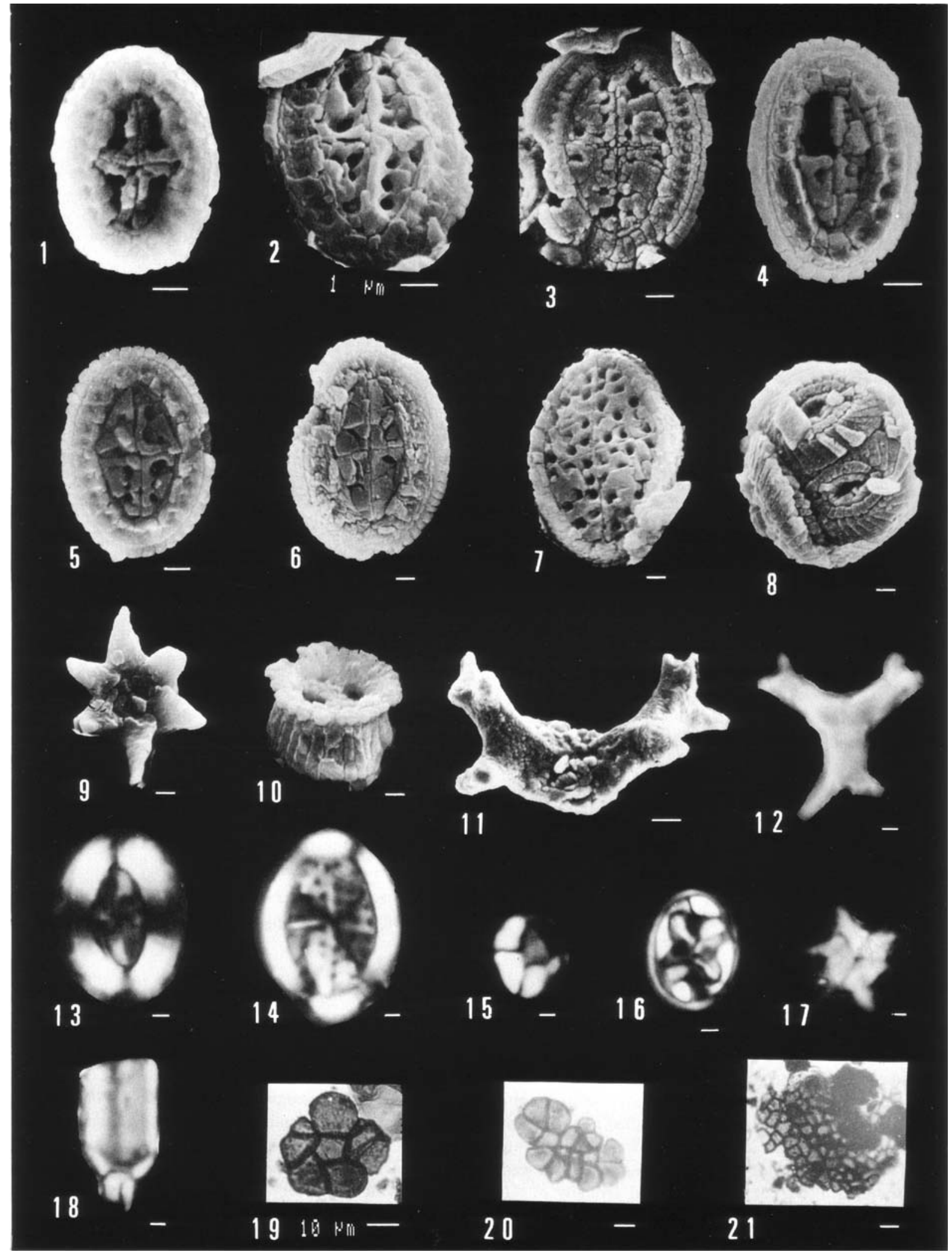




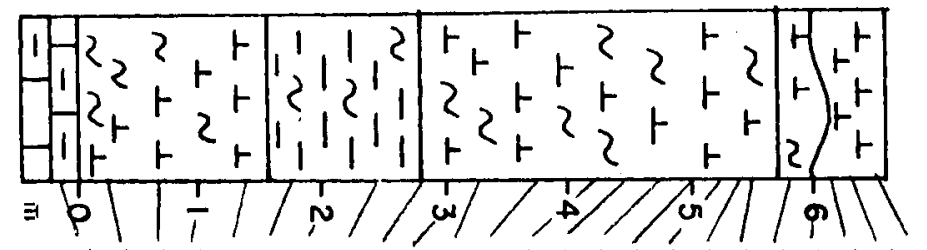

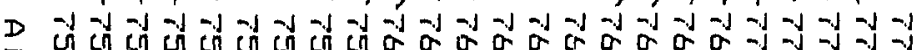

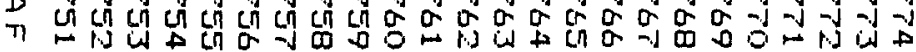

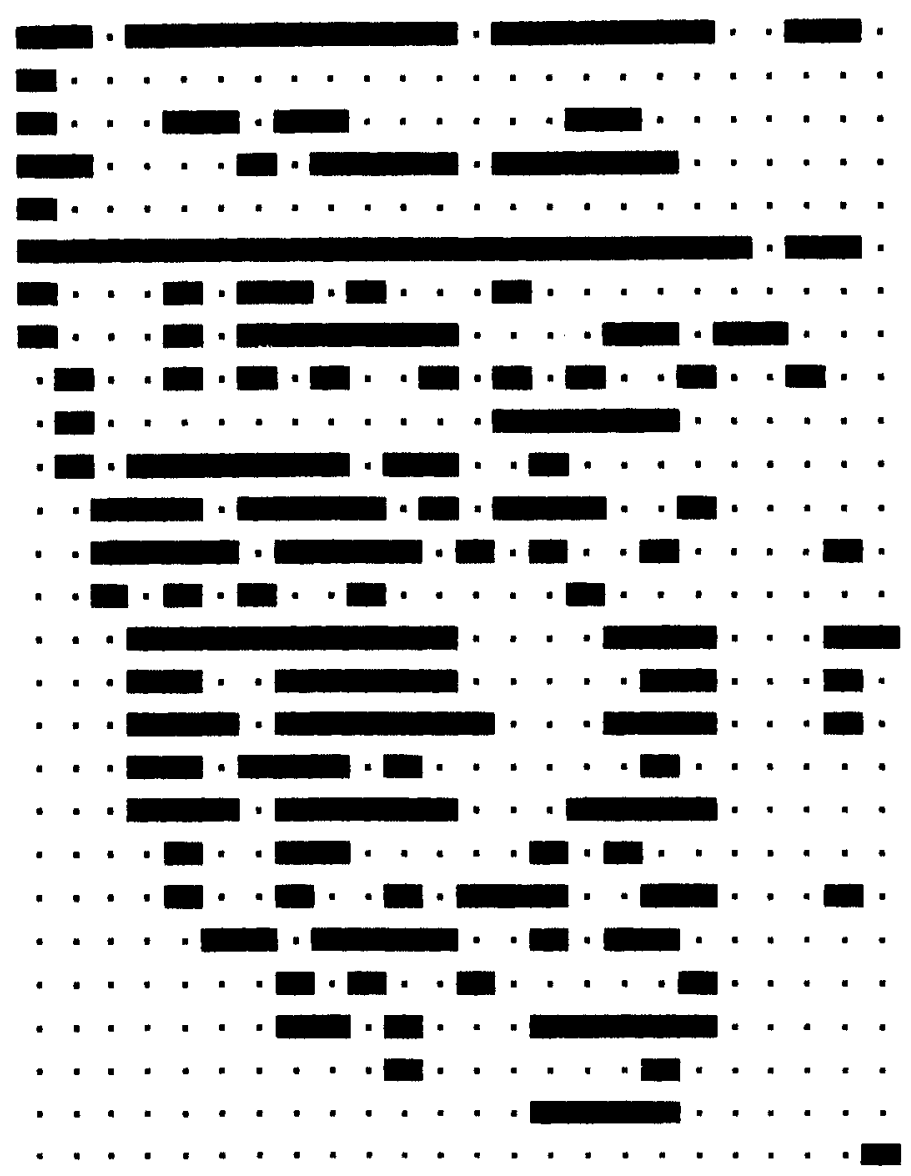

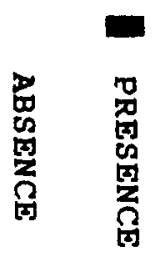

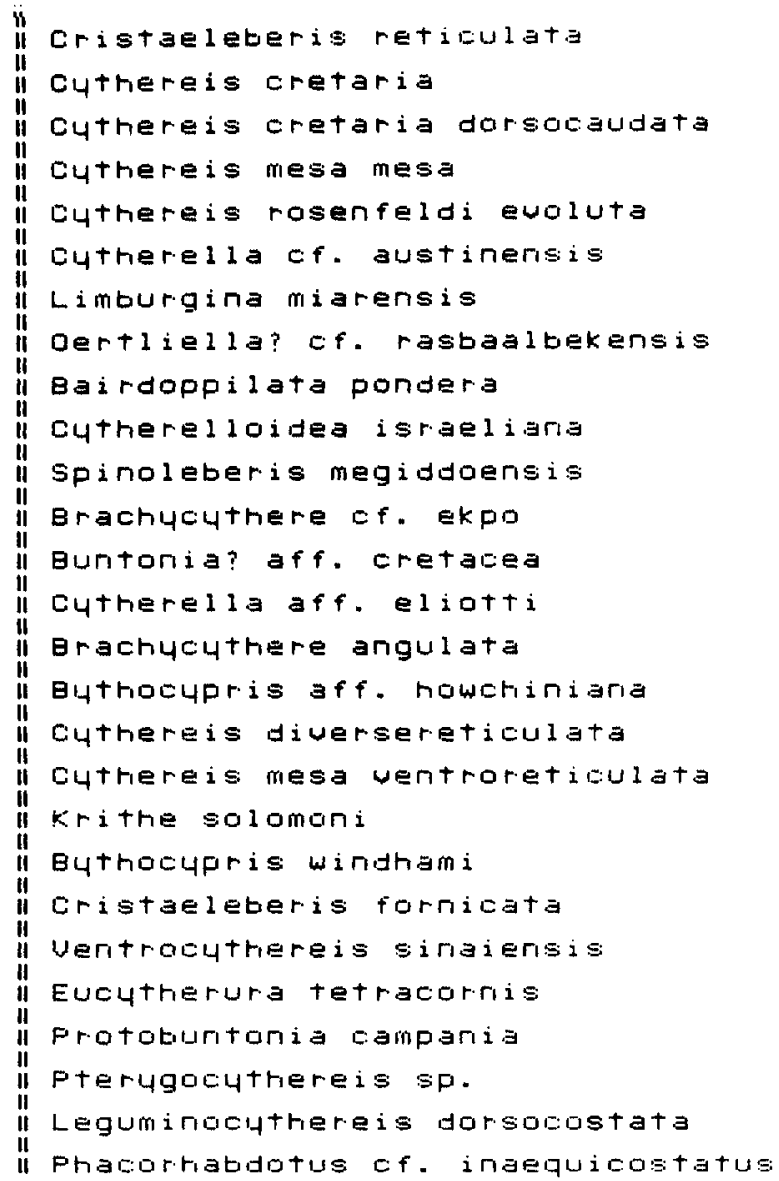

Fig.3. Range chart of ostracods in the Kabri Marl section.

although slightly decreasing in abundance in the upper part of the section where the benthonic species are more frequent and the faunas are rather poorly preserved. Most of the planktonic species belong to the genera Globigerinelloides, Hedbergella and Heterohelix (Fig.4). Globotrucanids are diversified and common, but represent only a minor component of the planktonic foraminiferal assemblage. Twenty Globotruncanidae species were identified throughout the section, the maximal diversity of this family is observed in its middle part (fifteen species, sample AF 767). The ranges of Globotruncanidae species enable a division of the Kabri Marl section into three planktonic foraminiferal zones which are in accord with the Tethyan zonation (Kuhry, 1970; Barr,
1972; Wonders, 1980; Dowsett, 1984; Robaszynski et al., 1984).

The lower Dicarinella asymetrica interval zone (Late Santonian) is determined by its index fossil (Pl.2, figs 5-6) as from the base of the succession up to the FO of Globotruncanita elevata (Pl.2, figs 8-9) at sample AF 755. From this sample up to sample AF $768, D$. asymetrica and $G$. elevata occur together and define the $D$. asymetrica - $G$. Elevata concurrent range zone. This zone was hitherto not observed in Israel (Reiss et al., 1985; AlmogiLabin et al., 1986; Honigstein et al., 1987). The overlying $G$. elevata interval zone (Early Campanian) starts above the extinction of D. asymetrica and ranges from sample AF 769 to the top of the section. 


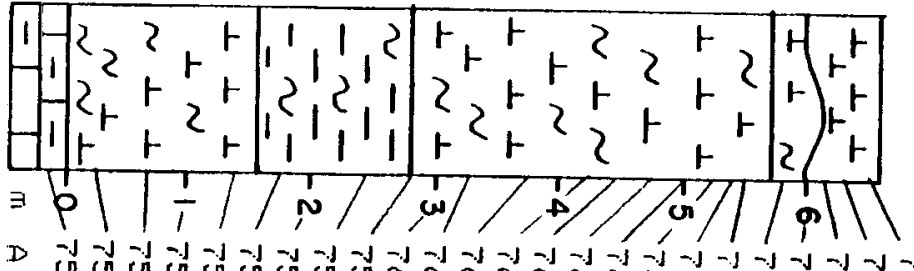

D 年

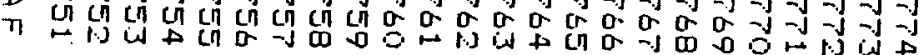

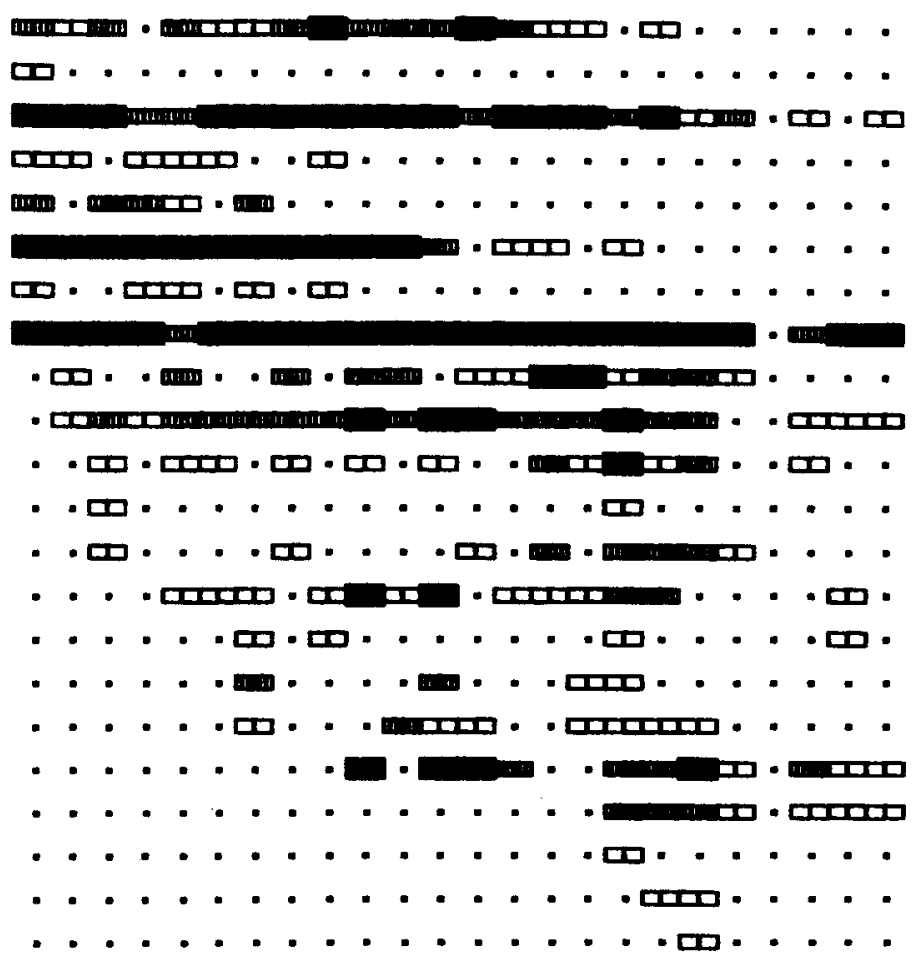

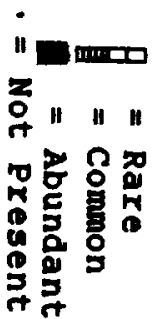

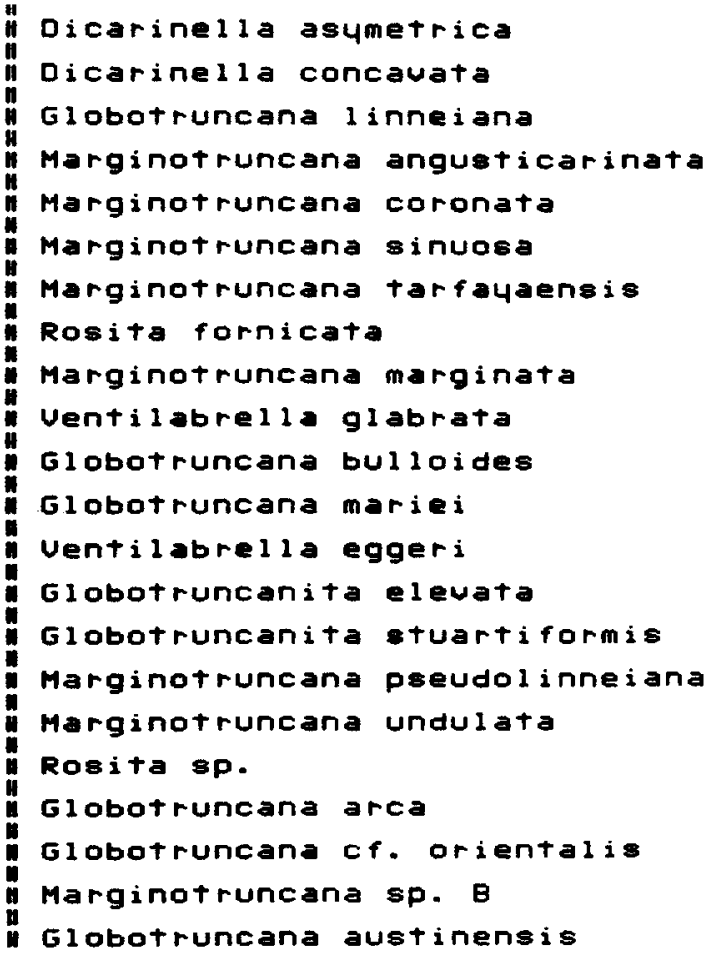

Fig.4. Distribution chart of selected planktonic foraminifera in the Kabri Marl section.

Besides these species the first and last occurrences of the following planktonic taxa are noteworthy: the LO of Dicarinella concavata in our samples is found within the lowermost $D$. asymetrica Zone, together with the FO of Globotruncana bulloides and $G$. mariei. The FO of Globotruncana arca (P1.2, fig.10) and Globotruncanita stuartiformis is recorded in the overlying samples of the $D$. asymetrica - G. elevata Zone. A gradual turnover from Marginotruncana species dominated faunas into assemblages composed mainly of species of Globotruncana and Globotruncanita is observed within this zone. The LO of several species of Marginotruncana is observed in this interval. $M$. coronata disappears first, then $M$. angusticarinata and $M$. tarfayaensis, followed by $M$. pseudolinneiana (Pl.2, fig.4) and $M$. sinuosa. The LO of $M$. undulata (Pl.2, fig.7) is recorded close to the base of the $G$. elevata Zone (AF 769). The ranges of most of these Marginotruncana species in Israel (Almogi-Labin et al., 1986 ) must therefore be extended into the $D$. asymetrica - $G$. elevata Zone.

The benthonic species, depicted in Fig. 5, add information to the planktonic assemblages. Within the $D$. asymetrica - $G$. elevata Zone the FO of several benthonic foraminifera index species is recorded. Gyroidinoides pseudosimiensis (Pl.2, fig.2) occurs at the base of this zone, Anomalinoides semicomplanata (Pl.2, fig.1) at its middle part and Neoflabellina rugosa (Pl.2, fig.3) from sample AF 766 upwards.

\section{PALAEOENVIRONMENT}

The Kabri Marl sequence represents one of the best, wellpreserved, and continuous Late Santonian-Early Campanian sections in Israel. Their floral and faunal content indicate deposition in an outer shelf to upper slope environment with minor fluctuations. The foraminiferal assemblage is dominated by planktonic species. The large species of the Globotruncanidae are well diversified. The ostracod assemblages, in general, indicate a warm (Cytherelloidea), outer shelf environment with minor changes to greater water depth (Krithe). The nannofossil and foraminifera assemblages show a somewhat deeper environment of deposition in the middle part of the succession (nanno-ooze), whereas in the lower and upper parts of the section a relative shallowing is suggested. This shallowing trend in the upper part of the section (AF 770 and upwards) was observed also by the increase in benthonic foraminifera and the decrease in the number of Globotruncanidae species. In this interval, ostracods are generally rare and lack the deeper water species Krithe solomoni. 


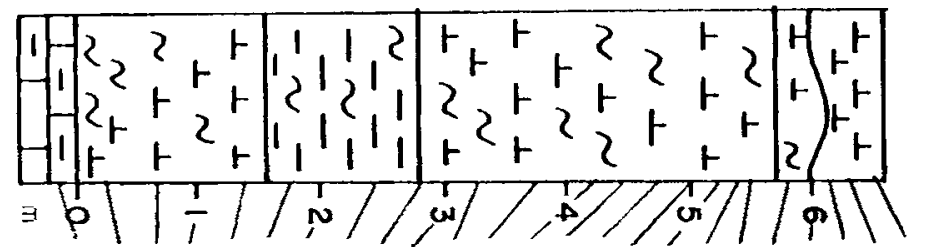

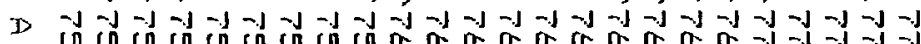

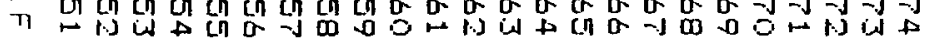

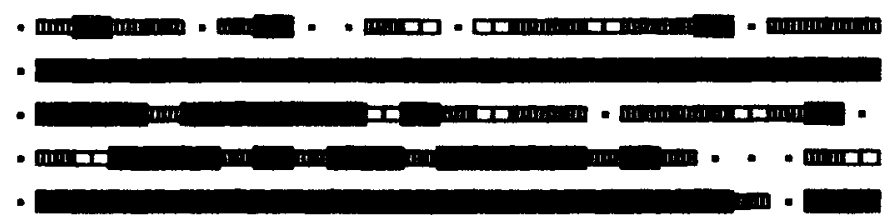

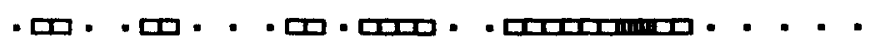
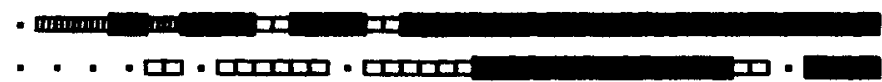

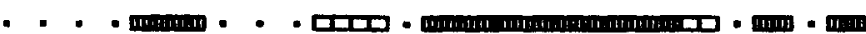

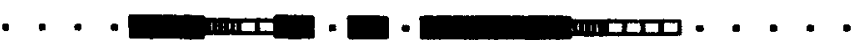

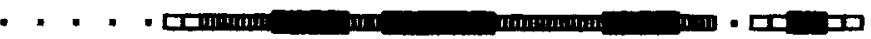

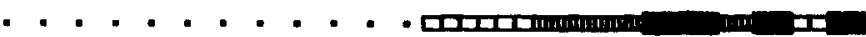

בص

".

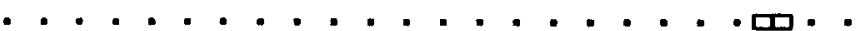

. . . . . . . . . . . . . . .. . . . .

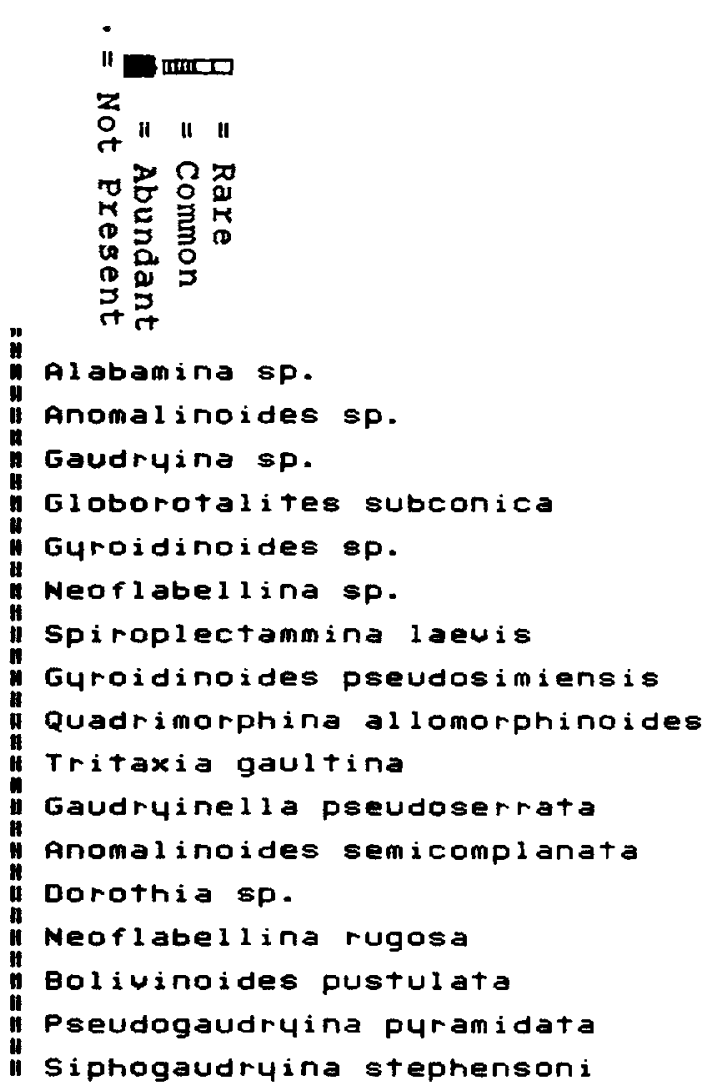

Fig.5. Distribution chart of selected benthonic foraminifera in the Kabri Marl section.

Explanation of Plate 2

Foraminifera and ostracods from the Kabri section.

Fig.1 Anomalinoides semicomplanata (Cushman \& Hedberg), lateral view, sample AF-769 (G. elewana Zone).

Fig.2. Gyroidinoides pseudosimiensis Reiss, umbilical view, sample AF-767 (D. asymetrica-G. clevata Zone).

Fig.3. Neoflabellina rugosa (d'Orbigny), sample AF-770 ( $G$. elevata Zone).

Fig.4. Marginotruncana pseudolinneiana Pessagno, umbilical view, sample AF-767 (D. asymetrtica - G. elevata Zone)

Fig.5. Dicarinella asymetrica (Sigal), umbilical view, sample AF-761 (D. asymetrica - G elevata Zone).

Fig.6. Dicarinella asymetrica (Sigal), lateral view, sample AF-763 (D. asymetrica-G. elevata Zone).

Fig.7. Marginotruncana undulata (Lehmann), umbilical view, sample AF-763 (D. asymetrica - G. elc'ata Zone).

Fig.8. Globotruncanita elevata (Brotzen), lateral view, sample AF-764 (D. asymetrica - G. elevata Zone).

Fig.9. Globotruncanita elevata (Brotzen), umbilical view, sample AF-761 (D. asvmetrica-G. elerata Zone)

Fig.10. Globotruncana arca (Cushman), umbilical view, sample AF-770 (G. elevata Zone).

Fig. 11. Leguminocythereis dorsocostata Honigstein, right view, sample AF-765 (S-4 Zone).

Fig. 12. Protohuntonia campania Honigstein, left view, sample AF-766 (S-4 Zone).

Fig. 13. Eucytherura tetracornis Honigstein, right view, sample AF-760) (S-4 Zone).

Fig. 14. Krithe solomoni Honigstein, right view, sample AF-766 (S-4 Zone). 


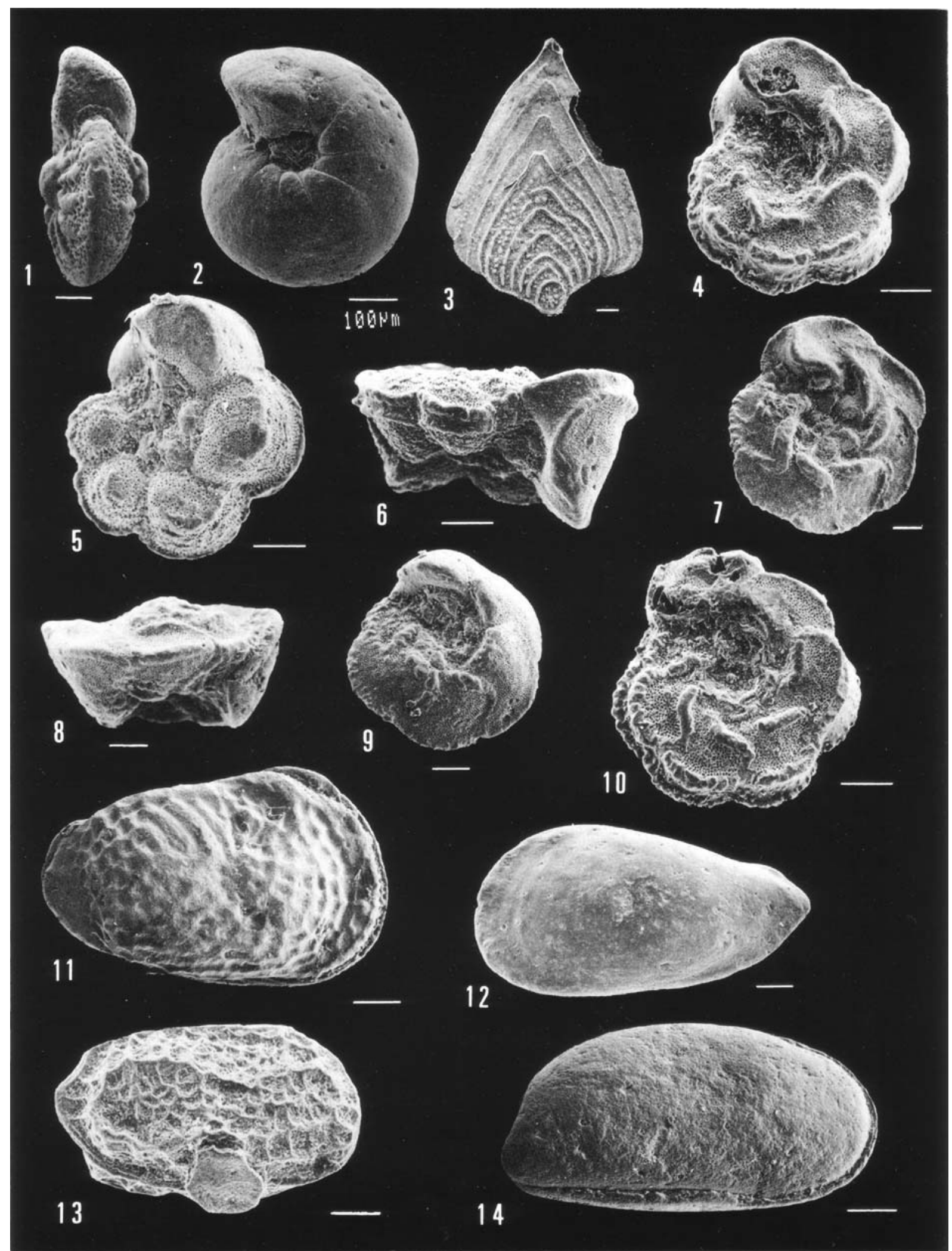




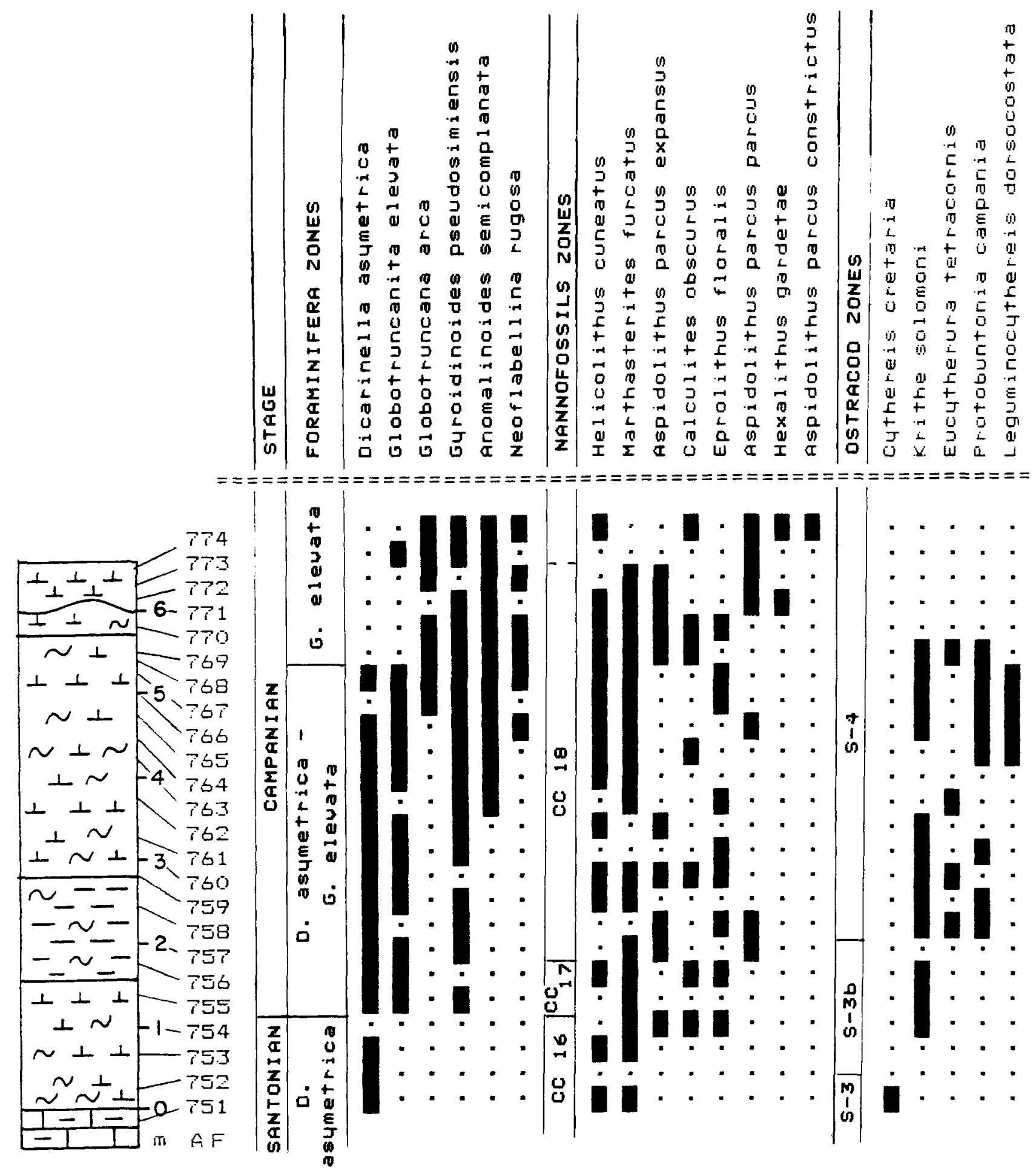

Fig.6. Stratigraphically important fossils and the Santonian-Campanian biozonation of the Kabri section. 
The relatively abundant terrestrial plant particles in sample $\mathrm{AF}$ 771 suggest a nearby landmass, serving as a source, at that time. This is supported by the relatively poor buoyancy of these particles, which could not have been transported by currents over a great distance..

\section{THE SANTONIAN/CAMPANIAN BOUNDARY}

The stage boundary between the Santonian and the Campanian was defined by the first occurrence of the ammonite Placenticeras bidorsatum (de Grossouvre, 1901; Haug, 1911). The calcareous nannofossil Santonian/Campanian biostratigraphy was studied by Stover (1966), Manivit (1971), Thierstein (1976), Sissingh (1977), Verbeek (1977) and Lambert (1981). The first occurrence of Aspidolithus parcus was regarded by some authors as the base level of the Campanian (Manivit, 1971; Thierstein, 1976; Verbeek, 1977). Others placed its first occurrence somewhat higher and not in the earliest Campanian (Sissingh, 1977; PerchNielsen, 1979, 1985; Lambert, 1981). Likewise, the same was suggested because of the position of the first occurrence of $A$. parcus above the top of the magnetic anomaly 34 at the Santonian/Campanian boundary (Stradner \& Steinmetz, 1984; Monechi \& Thierstein, 1985).

The foraminiferal biostratigraphical biozonation in the boreal and Tethyan regions is mainly based on the ranges of $D$. asymetrica and $G$. elevata, which allow for different interpretations. The Santonian/Campanian boundary is usually placed either at the last occurrence of $D$. asymetrica (Wonders, 1980; Robaszynski et al., 1984; Marks, 1984; Caron, 1985; Reiss et al., 1985; Almogi-Labin et al., 1986; Sliter, 1989) or at the first occurrence of G. elevata (Premoli Silva, 1977; Sigal, 1977; Weidich, 1984; Wagreich, 1988). Other foraminifera species, such as $G$. arca and $N$. rugosa were also used to mark this stage boundary (e.g. Birklund et al., 1984).

In Israel, the last occurrence of the common foraminiferal species $D$. asymetrica is generally used as the main marker of the Santonian/Campanian boundary (Reiss et al., 1985, 1986; Almogi-Labin et al., 1986; Honigstein et al., 1987; Gvirtzman et al., 1989). The occurrence of the other above mentioned index foraminifera is rather rare and sporadic at this level. In many Israeli sections an undefined interval separates the last occurrence of $D$. asymetric $a$ and the first occurrence of $G$. arca and $G$. elevata (Honigstein et al., 1987). Diagnostic planktonic foraminifera are absent in this interval. The nannofossil marker $A$. parcus was defined in Israel as Early (not earliest) Campanian in age (Gvirtzman et al., 1989). The lower boundary of the $L$. dorsocostata $(\mathrm{S}-4)$ ostracod assemblage zone generally marks the Santonian/Campanian boundary. The S-3b Subzone was hitherto defined only as Santonian/Campanian in age (Honigstein, 1984; Honigstein et al., 1987).

In the Kabri Marl section, the Santonian/Campanian boundary is defined in a multidisciplinary framework by nannofossils, foraminifera and ostracods (Fig.6); index ammonites are absent.

A combined study (ammonites, foraminifera and nannofossils) in the Gosau area, Austria, revealed that an ammonite, similar to the stage marker $P$. bidorsatum was found together with the $D$. Asymetrica - G. elevata concurrent range zone and below the first occurrence of $A$. parcus (Wagreich, 1988). This ammonite ( $P$. cf. bidorsatum; see Summesberger, 1979, 1985) is poorly preserved, but belongs, according to W.J. Kennedy (written comm., 1990), to $P$. bidorsatum. In Israel, age indicative ammonites were hitherto not observed at this level.

In the Kabri section, D. asymetrica and $G$. elevata were also found concurrently. In accordance with the stratigraphic position of $P$. bidorsatum and its correlation with the first occurrence of $G$. elevata in the Gosau area (Wagreich, 1988), the boundary in the Kabri section must be determined by the first occurrence of $G$. elevata in sample AF 755. Accordingly, the former foraminiferal stage determination in Israel and the Tethyan region must therefore also be corrected. The gradual overturn of the foraminiferal assemblages occurs thus mainly within the Early Campanian. The first occurrence of $A$. parcus parcus in sample AF 757 is found within the Early Campanian foraminiferal $D$. asymetrica - $G$. elevata Zone and indicates a position very close to the base of the Santonian-Campanian boundary. The base of the Early Campanian L. dorsocostata (S-4) ostracod zone at sample AF 758 is located about $1 \mathrm{~m}$ above the foraminiferal Campanian boundary and about $40 \mathrm{~cm}$ above the first occurrence of $A$. parcus parcus. The age of the underlying $S-3 b$ Subzone is now determined as latest Santonian-earliest Campanian. The datum lines of the different biozones, referring to the SantonianCampanian boundary, are located within the lower part of the Kabri Marl section and nearly coincide.

\section{ACKNOWLEDGEMENTS}

The authors wish to thank Dr W.J. Kennedy, Oxford University, U.K., for his comments on the Gosau ammonite definition. They also thank Bevie Katz for editing the manuscript, Tamara Beer and F. Calafateanu for preparing the samples, and $\mathrm{M}$. Dvorachek and Y, Levy for the SEM and light microscopy photographs. The latter are all from the Geological Survey of Israel, Jerusalem.

Manuscript received February 1990

Revised manuscript accepted November 1990

\section{REFERENCES}

Almogi-Labin, A., Reiss, Z. \& Caron, M. 1986. Senonian Globotruncanidae from Israel. Ecl. Geol. Helv, Basel, 79, 849-895.

Baida, U. 1964. On the geology of the Ga'aton - Hilazon area, western Galilee, Israel. Isr. J. Earth-Sci., Jerusalem, 13, 1-15

Barr, F.T. 1972. Cretaceous biostratigraphy and planktonic foraminifera of Libya. Micropaleontology, New York, 18, 1-46.

Birkelund, T., Hancock, J.M., Hart, M.B., Rawson, P.F., Remane, J., Robaszynski, F, Schmid, F. \& Surlyk, F. 1984. Cretaceous stage boundaries - proposals. Geol. Soc. Denmark Bull., Copenhagen, 33, 3-20.

Bukry, D. 1969. Upper Cretaceous coccoliths from Texas and Europe. Univ Kansas Paleont. Contrib., Lawrence, 51 (Protista), 1-79.

Caron, M. 1985. Cretaceous planktic foraminifera. In: Bolli, H.M., Saunders, J.B. \& Perch-Nielsen, K. (Eds). Plankton Stratigraphy, 17-86, Cambridge University Press, Cambridge.

Crux, J.A. 1982. Upper Cretaceous (Cenomanian to Campanian) calcareous nannofossils. In: Lord, A. (Ed.), A stratigraphical index of Calcareous Nannofossils, 81-135, Seel House Press, Liverpool for British Micropalaeontological Society.

de Grossouvre, A. 1901. Recherches sur la craie supérieur. 1: Stratigraphie générale. Mem. Serv. Carte géol. det. Fr., Paris, 7, 1-1013. 
Doeven, P.H. 1983. Cretaceous nannofossil stratigraphy and paleoecology of the Canadian Atlantic margin. Geol. Surv. Canada, Bull., Ottawa, 356, 1-70.

Dowsett, H.J. 1984. Documentation of the foraminiferal Santonian-Campanian boundary in the northeastem Gulf of Mexico. J. Foram. Res., Washington, 14, 129-133.

Flexer, A. 1968. Stratigraphy and facies development of Mount Scopus Group (Senonian-Paleocene) in Israel and adjacent countries. Isr. J. Earth-Sci., Jerusalem, 17, 85-114.

Gvirttzman, G., Moshkovitz, S. \& Reiss, Z. 1985. Senonian to Early Eocenc Mount Scopus Group in the Hashefela region, central Israel: structure and basin evolution. Isr.J. Earth-Sci., Jerusalem, 34, 172-192.

Gvirtzman, G., Almogi-Labin, A., Moshkovitz, S., Lewy, Z., Honigstein, A. \& Reiss, Z. 1989. Upper Cretaceous high-resolution multiple stratigraphy, northern margin of the Arabian platform, central Israel. Cretaceous Research, London 10, 107135 .

Hattner, J.G., Wind, F.H. \& Wise, S.W. 1980. The Santonian/Campanian boundary: Comparison of nearshore-offshore calcareous nannofossil assemblages. Cah. Micropal., Paris, 3, 9-26.

Hattner, J.G. \& Wise, S.W. 1980. Upper Cretaccous calcareous nannofossil biostratigraphy of South Carolina. S.C. Geol., South Carolina, 24, 41-117.

Haug, E. 1911. Traité de Géologie. Masson, Paris.

Honigstein, A. 1984. Senonian ostracodes from Israel, Isr. Geol. Surv., Bull, Jerusalem, 78, $1-48$

Honigstein, A., Almogi-Labin, A. \& Rosenfeld, A. 1987. Combined ostracod and planktonic foraminiferal biozones of Late Coniacian - Early Maastrichtian in Israel. J. Micropalaeont., London, 6, 41-60.

Kuhry, E. 1970. Some observations on the type material of Globotruncana elevata (Brontzen) and Globotruncana concavata (Brotzen). Rev. Espan. Micropaleont., Madrid, 2, 291-304

Lambert, B. 1981. Étude systématique des nannofossiles calcaires du Crétacé supérieur stratotypique (Coniacien, Santonien. Campanien). Répartition stratigraphique et biozonation. Thèse Doct. 3e cycle, Univ. Paris, 6, 1-291.

Lauer, G. 1975. Evolutionary trends in the Arkhangelskiellaceae (Calcareous nannoplankton) of the Upper Cretaceous of Central Oman, S.E. Arabia. Arch. Sci. Geneve, 28, 259-262.

Manivit, H. 1971. Nannofossiles calcaires du Crétacé Francais (AptienMaastrichtien). Thése Doct. 'Etat, Fac. Sci. Univ. d’Orsay, 1-167.

Marks, P. 1984. Proposal for the recognition of boundaries between Cretaceous stages by means of planktonic foraminiferal biostratigraphy. Geol. Soc. Denmark. Bull, 33, 163-169.

Monechi, S. \& Thierstein, H,R. 1985. Late Cretaceous-Eocene nannofossil and magnetostratigraphic correlations near Gubbio, Italy. Marine Micropal., Amsterdam, 9, 419-440.

Moshkovitz, S. 1967. First report on the occurrence of nannoplankton in Upper Cretaceous-Paleocene sediments of Israel. Jarb. Geol. Bundesanst., Wien, 110, 135-168.

Moshkovitz, S. 1984. Late Cretaceous calcareous nannofossil biostratigraphy of the Mount Scopus Group, Israel. Ist. Geol. Surv., Current Research, Jerusalem, 4. (1983-84), 46-55.

Moshkovitz, S. 1987. The Campanian calcareous nannofossil Bukryaster hayi (Bukry): ultramicrostructure and geologic distribution in Israel. J. Paleont., Chicago, 61, 1120-1124.

Naji, F. 1983. Kalkiges Nannoplankton aus der Oberkreide und dem Alttertiaer Nord-Jordaniens (Mittel-Santon bis Mittel-Eozaen). Gool. $\mathrm{Jb}$., Reihe B, Hannover, 55, 3-185.

Perch-Nielsen, K. 1979. Calcareous nannofossils from the Cretaceous between the North-Sea and the Mediterranean. Aspekte der Kreide Europas. IUGS Ser.A, Stuttgart, 6, 223-272.
Perch-Nielsen, K. 1985. Mesozoic calcareous nannofossils. In: Bolli, H.M., Saunders, J.B. \& Perch-Nielsen, K. (Eds). Plankton Stratigraphy, 329-426, Cambridge University Press, Cambridge.

Premoli Silva, 1. 1977. Upper Cretaceous-Paleocene magnetic stratigraphy at Gubbio, Italy. II. Biostratigraphy. Geol. Soc. Amer., Bull., Boulder, Color., 88, 371-374.

Reiss, Z., Almogi-Labin, A., Honigstein, A., Lewy, Z., Lipson-Benitah, S., Moshkovitz, S. \& Zaks, Y. 1985. Late Cretaceous multiple stratigraphic framework of Israel. Isr. J. Earth-Sci., Jerusalem, 34, 147-166.

Robaszynski, F., Caron, M., Gonzales Donoso, J.M. \& Wonders, A.A.H. (Eds) 1984. Atlas of Late Cretaceous Globotruncanids. Rev. Micropaleont., Paris, 26, 145305 .

Shafik, S. \& Stradner, H. 1971. Nannofossils from the Eastem Desert, Egypt, with reference to Maastrichtian nannofossils from the USSR. Jahrb. Geol. Bundesanst., Wien, spec vol. 17, 69-104.

Sigal, J. 1977. Essai de zonation du Crétacé méditerranéen à l'aide des foraminiféres planctoniques. Géol. Méditeranée Marseille, 4, 99-108.

Sissingh, W. 1977. Biostratigraphy of Cretaceous calcareous nannoplankton. Geol. Mijnbouw, Den Haag, 56, 37-65.

Sliter, W. 1989. Biostratigraphic zonation for Cretaceous planktonic foraminifera examined in thin sections. J. Foram. Res., Washington, 19, 1-19.

Stover, L.E. 1966. Cretaceous and associated nannofossils from France and the Netherlands. Micropaleontology, New York, 12, 133-167.

Stradner, H. \& Steinmetz, J. 1984. Cretaceous calcareous nannofossils from the Angola Basin, Deep Sea Drilling Project Site 530. Init. Rep. Deep Sea Drilling Proj, Washington, 75, 565-649.

Summesberger, H. 1979. Ein obersantone Ammonitenfauna aus dem Becken von Gosau (Oberoesterreich). Ann. Naturhist. Mus., Wein, 82, 109-176.

Summesberger, H. 1985. Ammonite zonation of the Gosau Group (Upper Cretaceous, Austria). Ann. Naturhist. Mus., Wein, 87, 145-166.

Thierstein, H.R. 1976. Mesozoic calcareous nannoplankton biostratigraphy of matine sediments. Marine Micropaleont., Amsterdam, 1, 325-362.

Verbeek, J.W. 1977. Calcareous nannoplankton biostratigraphy of Middle and Upper Cretaceous deposits in Tunisia, Southern Spain and France. Utrecht Micropaleont. Bull, 16, 1-157.

Wagreich, M. 1988. Nannoplankton- und Foraminiferen-Feinstratigraphie des Santon-Untercampans der Gosauschichtgruppe von Gossau-Russbach (Oberoesterr.-Salzburg). Mitt. Ges. Geol. Bergbaustud. Oesterr., Wien, 34/35. 279-294.

Weidich, K.F. 1984. Feinstratigraphie, Taxonomie planktonischer Foraminiferen und Paloekologie der Foraminiferengesamtfauna der kalkalpinen tieferen Oberkreide (Untercenoman-Untercapan) der Bayerischen Alpen. Bayer. Akad.Wiss. math.naturwiss. Kl. Abh., N.F., Muenchen, 162, 1-151.

Wise, S.W. 1983. Mesozoic and Cenozoic calcareous nannofossils recovered by Deep Sea Drilling Project Leg 71 in the Falkland Plateau region, Southwest Atlantic Ocean. Intial Rep. Deep Sea Drilling Proj., Washington. 71. 481-550.

Wonders, A.A.H. 1980. Middle and Late Cretaceous planktic foraminifera of the western Mediterranean area. Utrecht Micropaleont. Bull.. 24. 1-1.36. 